\title{
PERMAINAN MATEMATIKA MONOPOLI TIC TAC TOE YANG EFEKTIF DALAM MEMPELAJARI PENJUMLAHAN DAN PENGURANGAN BILANGAN BULAT
}

\author{
MONOPOLI TIC TAC TOE AS AN EFFECTIVE MATHEMATICS GAME TO LEARN \\ ADDITION AND SUBSTRACTION INTEGER NUMBER
}

\author{
Negara Mangkubumi K \\ SMP Negeri 2 Sengkang Kecamatan Tempe Kabupaten Wajo \\ negaramangkubumi87@gmail.com
}

Naskah diterima: 14/04/2016, direvisi akhir: 06/05/2016, disetujui: 20/05/2016

\begin{abstract}
Abstrak: Penelitian ini bertujuan untuk mengembangkan media permainan matematika monopoli tic tac toe yang efektif dan praktis untuk menarik siswa mempelajari penjumlahan dan pengurangan bilangan bulat. Penelitian ini dilatarbelakangi masih banyaknya siswa yang belum mahir melakukan operasi hitung penjumlahan dan pengurangan bilangan bulat yang merupakan materi awal yang diajarkan di kelas VII SMP sehingga keberhasilan pembelajaran kurang maksimal. Model desain pembelajaran yang digunakan adalah desain model ADDIE (Analyze, Design, Development, Implementation, and Evaluate). Pada tahap pengembangan (Development), metode pengembangan media pembelajaran ini menggunakan beberapa langkah model pengembangan (Borg and Gall), terdiri dari 5 tahapan utama, yaitu 1) Desain awal produk, 2) uji coba produk tahap I, 3) Revisi produk operasional, 4) Uji coba produk tahap II, dan 5) Produk. Subyek uji coba penelitian sejumlah 28 siswa. Instrumen yang digunakan adalah lembar validasi kelayakan media pembelajaran, angket respon siswa, dan foto dokumentasi. Hasil Penelitian menunjukkan telah berhasil membangkitkan minat siswa untuk mempelajari matematika khususnya penjumlahan dan pengurangan bilangan bulat karena aspek keefektifan dan kepraktisan pada kriteria layak untuk digunakan serta respon siswa yang semakin positif sehingga media yang dikembangkan ini diharapkan mampu meningkatkan hasil belajar matematika siswa pada umumnya. Dari hasil tersebut dapat disimpulkan bahwa permainan monopoli tic tac toe mampu membuat siswa untuk berusaha mencari tahu tentang materi penjumlahan dan pengurangan bilangan bulat dan dapat memberikan pengalaman baru yang berarti bagi siswa. Dengan adanya penelitian ini diharapkan para guru maupun peneliti termotivasi menemukan formula-formula baru bagi sistem pembelajaran yang lebih inovatif untuk meningkatkan mutu pendidikan.
\end{abstract}

Kata Kunci: Media pembelajaran, penelitian pengembangan, tic tac toe, penjumlahan dan pengurangan bilangan bulat.

Abstract: This research was aimed developing the mathematics game media named monopoli tic tac toe which attrack students to learn about additon and substraction of integer number more effectively and practically. It was based of some students still uncapable to solve this operation number in grade VII SMP therefore impact deficient of learning success. The procedure used in this research was the ADDIE (Analyze, Design, Development, Implementation, and Evaluate). The Development used Borg and Gall model which consisted of five stages, namely: 1) first product design, 2) first trial, 3) revise operational product, 4) second trial, and 5) final product. The subjects were 28 students. The instruments consist of validation learning media form, student response form, and documentation photos. The result of research showed the increase of student interests to learn mathematics, specially the addition and substraction integer number. It causes by effective and practical aspects of 
suitables criteria and response of students more positive therefore this media could increase the result of learning in generally. The conclution of the results are monopoli tic tac toe interests student to have more effort to know about addition and substraction of integer number. Then, giving new experience for the student also. Hopefully by this research, the teacher and researcher were motivated to discover new formulas of teaching and learning inovation which improve the education quality.

Keywords: learning media, development research, tic tac toe, addition and substraction integer number.

\section{PENDAHULUAN}

Pendidikan nasional Indonesia harus sejalan dengan amanat Pasal 31 UUD Negara RI Tahun 1945 tentang Pendidikan dan Kebudayaan. Secara operasional pelaksanaan pendidikan harus merupakan realisasi UU RI No. 20 Tahun 2003 tentang Sistem Pendidikan Nasional. Oleh karena itu, pelaksanaan pendidikan nasional harus menjamin pemerataan dan peningkatan mutu pendidikan nasional di tengah perubahan global. Melalui pendidikan nasional setiap warga negara Indonesia diharapkan menjadi manusia yang bertakwa kepada Tuhan Yang Maha Esa, berakhlak mulia, cerdas, produktif, berdaya saing tinggi, dan bermartabat di tengah pergaulan internasional. Dalam hubungan ini segala upaya perlu dilakukan agar pelaksanaan pendidikan nasional dapat berhasil sehingga tujuan pendidikan nasional dapat tercapai.

Dewasa ini terjadi perubahan paradigma pembelajaran dari yang berpusat pada guru ke yang berpusat pada peserta didik. Pembelajaran yang berpusat pada peserta didik menjamin terlaksananya pembelajaran bermakna. Para peserta didik didorong membangun sendiri pemahamannya, dan guru berperan sebagai fasilitator. Guru bukanlah satu-satunya sumber pengetahuan bagi peserta didik. Sumber pengetahuan tersebut sesungguhnya demikian banyak dan semuanya berada dalam lingkungan sekitar, sehingga peserta didik dituntut lebih aktif dan kreatif dalam belajar.

Perubahan paradigma pembelajaran ini menuntut perubahan proses pembelajaran dan hal lain termasuk yang berkaitan dengan sarana dan prasarana. Sarana dan prasarana seyogyanya dirancang agar pembelajaran yang berpusat pada peserta didik dapat terlaksana secara optimal. Oleh karena itu sudah seharusnya pendidikan didesain guna memberikan pemahaman serta meningkatkan prestasi belajar peserta didik (siswa).

Prestasi belajar siswa disekolah sering diindikasikan dengan permasalahan belajar dari siswa tersebut dalam memahami materi. 
Indikasi ini dimungkinkan karena factor belajar siswa yang kurang efektif, bahkan siswa sendiri tidak merasa termotivasi didalam mengikuti pembelajaran dikelas karena pembelajaran yang kurang menarik. Sehingga menyebabkan siswa kurang atau bahkan tidak memahami materi yang bersifatsukar yang di berikan oleh guru tersebut. Kecenderungan pembelajaran yang kurang menarik ini merupakan hal yang wajar dialami oleh guru yang tidak memahami kebutuhan dari siswa tersebut baik dalam karakteristik, maupun dalam pengembangan ilmu. Dalam hal ini peran seorang guru sebagai pengembang ilmu sangat besar untuk memilih dan melaksanakan pembelajaran yang tepat dan efisien bagi peserta didik bukan hanya pembelajaran berbasis konvensional. Pembelajaran yang baik dapat ditunjang dari suasana pembelajaran yang kondusif serta hubungan komunikasi antara guru dan siswa dapat berjalan dengan baik. Untuk itu, dalam proses komunikasi, penggunaan media hanya satu dari empat komponen yang harus ada, yaitu sumber informasi, informasi, penerima informasi dan media itu sendiri. Jika salah satu saja dari empat komponen ini tidak ada, maka proses komunikasi tidak akan berjalan.Menurut Dr. Nana Sudjana, media pengajaran dapat mempertinggi proses belajar siswa dalam pengajaran yang pada gilirannya diharapkan dapat mempertinggi hasil belajar yang dicapainya. Karena media mempunyai beberapa manfaat yang berkontribusi dalam meningkatkan hasil belajar siswa.
Ketersediaan media dan alat peraga matematika di SMP Negeri 2 Sengkang saat ini menurut pengamatan peneliti memang sudah ada yang berupa paket Matematika dari pemerintah, namun yang secara spesifik untuk menunjang kemampuan mengingat, ketertarikan memahami, dan kemauan atau motivasi mempelajari operasi hitung penjumlahan dan pengurangan bilangan bulat belum tersedia. Meskipun dalam proses pembelajaran telah digunakan alat peraga sederhana untuk menjelaskan konsep penjumlahan dan pengurangan bilangan bulat, hanya sebagian kecil siswa untuk mau mencari tahu bahkan sebagaian besar siswa terkesan cuek. Hal ini terjadi karena masa transisi usia diikuti karakteristik siswa SD menjadi siswa SMP, karena materi penjumlahan dan pengurangan bilangan bulat adalah materi awal yang diajarkan di kelas VII SMP sehingga keberhasilan pembelajaran kurang maksimal.

Masih banyaknya siswa yang belum mahir melakukan operasi hitung penjumlahan dan pengurangan bilangan bulat yang terjadi tiap tahunnya menjadi permasalahan serius bagi guru matematika di SMP Negeri 2 Sengkang ?? Apa diantara masalah tsb. Ini tentunya berpengaruh pada kemampuan siswa dalam menyelesaikan soal matematika dan juga akan berimbas pada mata pelajaran lainnya yaitu IPA Fisika.

Berangkat dari hal tersebut penggunaan media yang menarik dan disesuaikan dengan usia serta karakteristik siswa dalam kelas perlu 
dikembangkan atas dasar asumsi bahwa proses komunikasi di dalam pembelajaran akan lebih bermakna (menarik minat siswa dan memberikan kemudahan untuk memahami materi karena penyajiannya yang interaktif), sehingga tujuan penelitian yang diharapkan dapat meningkatkan kualitas pembelajaran dan membuat pembelajaran matematika menjadi menyenangkan bisa tercapai. Oleh karena itu, dari uraian di atas peneliti merumuskan masalah "Bagaimana media permainan matematika monopoli tic tac toe yang efektif untuk menarik minat siswa Sekolah Menengah Pertama mempelajari penjumlahan dan pengurangan bilangan bulat?"

\section{KAJIAN LITERATUR}

\section{Pembelajaran Inovatif}

Aktivitas proses pembelajaran merupakan inti dari proses pendidikan, sedangkan guru adalah salah satu pemegang utama di dalam menggerakkan kemajuan dan perkembangan dunia pendidikan. Tugas utama seseorang guru ialah mendidik, mengajar, membimbing, melatih. Oleh karenanya, tanggung jawab keberhasilan pendidikan berada di pundak guru. Agar proses pembelajaran berhasil dan mutu pendidikan meningkat, dibutuhkan guru yang memiliki wawasan pengetahuan dan keterampilan sehingga mampu menjadikan proses pembelajaran aktif dan menciptakan suasana pembelajaran inovatif, kreatif, dan menyenangkan. Salah satu diantaranya adalah pembuatan karya inovasi pembelajaran dalam menunjang keberhasilan proses belajar mengajar di kelas.

Dalam konteks program belajar mengajar, program pembelajaran yang inovatif dapat berarti program yang dibuat sebagai upaya mencari pemecahan suatu masalah. Itu disebabkan, karena program pembelajaran tersebut belum pernah dilakukan atau program pembelajaran yang sejenis sedang dijalankan akan tetapi perlu perbaikan. Program pembelajaran inovatif adalah program pembelajaran yang langsung memecahkan permasalahan yang sedang dihadapi oleh kelas berdasarkan kondisi kelas. Pada gilirannya program pembelajaran tersebut akan memberi sumbangan terhadap usaha peningkatan mutu sekolah secara keseluruhan.

$$
\text { Rogers dan Shoemaker }
$$
mengartikan inovasi sebagai ide-ide baru, praktek-praktek baru, atau objek-objek yang dapat dirasakan sebagai sesuatu yang baru oleh individu atau peserta didik. Pengertian baru disini mengandung makna bukan sekadar baru diketahui oleh pikiran (cognitife), melainkan juga baru karena belum dapat diterima secara luas oleh seluruh peserta didik dalam arti sikap (attitude) dan juga baru dalam pengertian belum diterima dan diterapkan oleh peserta didik. Pembelajaran inovatif adalah pembelajaran yang dikemas oleh pebelajar atas dorongan gagasan barunya yang merupakan produk dari learning how to learn untuk melakukan langkah-langkah belajar, sehingga memperoleh kemajuan hasil belajar. Berikut ini 
beberapa teori yang mendasari pembelajaran inovatif:

\section{Teori Kognitif}

Perilaku yang tidak tampak dapat dipelajari secara ilmiah seperti pada perilaku yang tampak. Hal itulah yang mendasari teori kognitif. Perilaku yang tidak tampak merupakan proses internal yang merupakan hasil kerja potensi psikis. David Ausubel berpendapat bahwa belajar itu terjadi dalam organisme manusia melalui proses yang bermakna yang menghubungkan peristiwa atau butir baru pada aspek kognitif yang ada. Makna bukanlah respon yang tersirat tetapi merupakan pengalaman sadar yang diartikulasikan secara jelas dan dibedakan secara tepat. Hal tersebut dapat muncul manakala tanda, lambang, konsep, atau proposisi yang bermakna dikaitkan dan dipadukan dalam struktur kognitif individual yang berasal dari basis substansial dan nonkebiasaan.

Teori kognitif lebih mengandalkan pikiran dan konsep dasar yang dimiliki pembelajar daripada pengalaman. Kognitif amat menjauhi model menghafal. Yang diorientasikan secara mendalam adalah belajar bermakna. Tiap proses pembelajaran haruslah bermakna yang mampu mengelaborasi kognisi seseorang. Situasi belajar apa pun dapat bermakna apabila pembelajar mempunyai seperangkat pembelajaran yang bermakna, yakni penghubungan tugas belajar yang baru dengan apa yang sudah diketahuinya. Tugas belajar tersebut secara potensial akan bermakna bagi pembelajar.

\section{Teori Humanistik atau Teori Sosial}

Proses belajar tidak hanya terjadi karena seseorang mendapatkan stimulus dari lingkungannya dan meresponnya tetapi terjadi pula karena pelaku belajar berkomunikasi dengan individu lainnya. Proses belajar terjadi karena komunikasi personal. Dalam diri pelaku belajar atau siswa terjadi transaksi akibat komunikasi dua arah atau lebih yang masingmasing mendapat kesempatan, baik selaku inisiator maupun mereaksi komunikasi. Komunikasi itu dapat berlangsung secara akrab, intensif, dan mendalam. Oleh karena itu, teori humanistik dikembangkan menjadi teori sosial, yang dikembangkan oleh Bandura. Menurut Bandura (dalam Dahar, 1989) dalam belajar berdasarkan teori sosial terdapat empat fase, yaitu: perhatian, retensi, reproduksi, dan motivasi. Manusia akan belajar apa saja sepanjang dia membutuhkan. Dia tidak peduli dengan kognitif yang aktual atau pengalaman yang telah dialaminya.

Menurut Rogers, dalam konteks belajar yang diciptakan, manusia akan belajar apa saja yang dia butuhkan. Konsep Rogers tersebut saat ini memberikan perubahan besar bagi konsep pembelajaran yang bertumpu pada pembelajar. Pembelajar itu sangat individual. Oleh karena itu, jika ingin berhasil dalam pembelajaran, perhatikan kebutuhan individual dalam belajar. Untuk mengadaptasi konsep Rogers dalam pembelajaran, kita perlu 
memahami bahwa pembelajar adalah organisme yang butuh memahami dirinya sendiri dan mengkomunikasikan dirinya kepada orang lain secara bebas dan aman. Guru sebagai fasilitator harus memberikan konteks pengiring untuk belajar dan tidak memberikan misi pribadi guru untuk dijejalkan ke siswa berdasarkan pengalaman guru sebelumnya.

\section{Teori Gestalt}

Psikologi Gestalt memandang unsurunsur yang terlibat dalam proses belajar tidak terpisahkan tetapi merupakan totalitas dalam membentuk medan belajar. Oleh karena itu teori Gestalt disebut pula dengan teori medan. Gestalt berarti bentuk yang terdiri atas unsurunsurnya. Beberapa unsur yang distruktur dapat menghasilkan efek sinergis yang merupakan Gestalt.

Menurut Lewin perubahan tingkah laku merupakan indikator hasil belajar diperoleh karena lingkungan yang disediakan difungsikan untuk memfasilitasi potensi internal yang terdapat dalam diri pelaku belajar. Lingkungan tidak secara langsung mengubah tingkah laku. Perpustakaan sekolah tidak akan berfungsi jika guru tidak memfungsikannya. Selain itu, motivasi merupakan faktor penting dalam pembelajaran. Motivasi adalah faktor yang dapat mendorong setiap individu untuk berperilaku. Motivasi muncul karena adanya daya tarik tertentu. Di samping itu, motivasi juga bisa muncul karena pengalaman yang menyenangkan, misalnya pengalaman kesuksesan.
Dari kajian teori di atas tentang pembelajaran, maka beberapa konsep yang dapat dipahami dari makna pembelajaran inovatif, antara lain.

1) Model pembelajaran inovatif dan partisipatif dapat menumbuhkembangkan pilar-pilar pembelajaran pada siswa, antara lain: learning to know (belajar mengetahui), learning to do (belajar berbuat), learning to gether (belajar hidup bersama), dan learning to be (belajar menjadi seseorang) (Djohar, 1999);

2) Model pembelajaran inovatif dan partisipatif tersebut mampu mendorong siswa untuk mengembangkan semua potensi dirinya secara maksimal, dengan ditandai oleh keterlibatan siswa secara aktif, kreatif dan inovatif selama proses pembelajaran di sekolah;

3) Model pembelajaran inovatif dan partisipatif tersebut mampu mengefektifkan pencapaian tujuan pembelajaran atau tujuan pendidikan; dan

4) Model pembelajaran inovatif dan partisipatif tersebut mampu mendorong siswa untuk melakukan perubahan perilaku secara positif dalam berbagai aspek kehidupan (baik secara pribadi atau kelompok). Jadi, pembelajaran inovatif dan partisipatif adalah pembelajaran yang berorientasi pada strategi, metode atau upaya meningkatkan semua kemampuan positif siswa agar dapat meningkatkan kualitas intelektual (penguasaan Iptek), kualitas emosional (kepribadian) dan 
kualitas spiritual sehingga siap menyongsong masa depan yang penuh kompetisi. Dalam proses pengembangan potensi atau kemampuan siswa tersebut, pembelajaran inovatif dan partisipatif menempatkan posisi dan peran-peran siswa sebagai sebagai pihak yang paling aktif (paling sentral), guru hanya sekedar sebagai pembimbing, motivator dan evaluator kegiatan pembelajaran siswa.

Oleh karena itu, Model pembelajaran inovatif dan partisipatif dapat dilakukan oleh guru melalui pembuatan atau pengembangan karya inovasi pembelajaran di kelas yang dapat menumbuhkembangkan pilar- pilar pembelajaran pada siswa, mampu mendorong siswa untuk mengembangkan semua potensi dirinya secara maksimal, dengan ditandai oleh keterlibatan siswa secara aktif, kreatif dan inovatif selama proses pembelajaran di sekolah. Mampu mengefektifkan pencapaian tujuan pembelajaran atau tujuan pendidikan; dan mampu mendorong siswa untuk melakukan perubahan perilaku secara positif dalam berbagai aspek kehidupan (baik secara pribadi atau kelompok).

\section{Motivasi Belajar}

Proses belajar hendaknya lebih mengembangkan motivasi intrinsic siswa. Motivasi intrinsik adalah hal dan keadaan yang berasal dari dalam diri siswa sendiri yang dapat mendorongnya melakukan tindakan belajar. Dalam perspektif psikologi kognitif, motivasi yang lebih signifikan bagi siswa adalah motivasi intrinsik (bukan ekstrinsik) karena lebih murni dan langgeng serta tidak bergantung pada dorongan atau pengaruh orang lain. Dorongan mencapai prestasi dan memiliki pengetahuan dan keterampilan untuk masa depan, umpamanya, memberi pengaruh lebih kuat dan relatif lebih langgeng dibandingkan dengan dorongan hadiah atau dorongan keharusan dari orangtua dan guru. Motivasi belajar siswa akan meningkat apabila ditunjang oleh pendekatan yang lebih berpusat pada siswa (student centered learning). Guru mendorong siswa untuk aktif mencari, menemukan dan memecahkan masalahnya sendiri. Ia tidak hanya menyuapi murid, juga tidak seperti orang yang menuangkan air ke dalam ember.

Syaiful Bahri Djamarah (2008: 152) mengemukakan motivasi adalah gejala psikologis dalam bentuk dorongan yang timbul pada diri seseorang sadar atau tidak sadar untuk melakukan suatu tindakan dengan tujuan tertentu.

Berdasarkan pendapat yang dikemukakan oleh Sardiman (2011: 83), motivasi yang ada pada diri setiap orang itu memiliki ciri-ciri sebagai berikut:

a. Tekun menghadapi tugas.

b. Ulet menghadapi kesulitan.

c. Menunjukkan minat terhadap bermacammacam masalah untuk orang dewasa.

d. Lebih senang bekerja mandiri.

e. Cepet bosan pada tugas-tugas yang rutin.

f. Dapat mempertahankan pendapatnya. 
g. Tidak mudah melepaskan hal yang diyakini itu.

h. Senang mencari dan memecahkan masalah soal-soal.

\section{Permainan Monopoli Tic Tac Toe}

Menurut kodratnya anak-anak senang bermain. Jika pelajaran matematika dapat disajikan dalam bentuk permaianan yang menyenangkan bagi anak, maka dalam diri anak akan tumbuh pula rasa senang belajar matematika. Dengan permainan matematika anak akan lebih mudah memahami konsep abstrak dalam matematika yang disajikan dalam bentuk konkret, sehingga dalam diri anak timbul rasa senang matematika. Hal demikian dapat memperkecil peluang tumbuh berkembangnya anggapan bahwa pelajaran matematika sulit dan merupakan momok yang menakutkan. Sebagai gantinya terpupuklah minat untuk mempelajari matematika. Permainan matematika yang diberikan pun harus disesuaikan dengan karakteristik dan usia siswa.

Model permainan monopoli tic tac toe merupakan permainan monopoli dan permainan tic tac toe yang dikombinasikan menjadi satu permainan matematika. Dalam permainan monopoli, pemain berlomba untuk mengumpulkan kekayaan melalui satu perlaksanaan satu sistem ekonomi mainan yang melibatkan pembelian, penyewaan dan pertukaran tanah dengan menggunakan duit mainan. Pemain mengambil giliran untuk melemparkan dadu dan bergerak di sekeliling papan permainan mengikuti bilangan yang diperoleh dengan lemparan dadu tadi.

Namun model permainan monopoli paikem ?? nama mainan?? Huruf besar yang dikombinasikan dengan permianan tic tac toe (ini juga nama dgn $\mathrm{HB}$ ) yang dibuat pada dasarnya sama dengan bentuk permainan monopoli biasa yaitu untuk menguasai. Menguasai pada permainan monopoli paikem adalah bukan hanya menguasai wilayah saja seperti pada permainan monopoli biasa tetapi menguasai pengetahuan dan strategi.

Sedangkan Permainan Tic Tac Toe lebih dikenal sebagai permainan catur jawa jika di Indonesia. Bahkan dalam pengembangan permainan ini, Tic Tac Toe ada yang dalam bentuk tiga dimensi. Permainan ini sangat unik karena menggunakan papan dengan grid $3 \times 3$ atau lebih yang dimainkan oleh dua orang pemain dan para pemain bermain dengan menggunakan bidak berbentuk " $X$ " atau "O" membentuk satu barisan untuk memenangkan permainan. Permainan Tic-Tac-Toe sangatlah sederhana dipahami oleh permainan anak-anak. Pada awal permainan, papan dikosongkan. Kedua pemain, $\mathrm{X}$ dan $\mathrm{O}$, akan menempatkan biji-bijinya ke atas papan, sekali pasang satu biji. Pemain yang mampu menempatkan tiga bijinya dalam satu garis (vertikal, horizontal, diagonal) itulah yang menang. Dan dikatakan seri apabila papan telah penuh maupun tidak ada yang menang.

Bentuk dari model permainan monopoli tic tac toe paikem adalah memasukan petak kartu 
dana umum dan kartu kesempatan berisi instruksi yang harus dilakukan oleh peserta permainan. Sementara papan grid permainan tic tac toe yang digunakan adalah papan grid berukuran 6 x 6 karena menggunakan dua dadu sebagai alat permaianan seperti pada permainan monopoli biasa

METODOLOGI PENELITIAN Desain Pembelajaran
Permainan matematika monopoli tic tac toe ini menggunakan model desain pembelajaran yang memasukkan penggunaan unsur pemanfaatan media di dalamnya untuk merealisasikan pembelajaran yang efektif, efisien, dan menarik yakni model desain pembelajaran ADDIE (Analyze, Design, Development, Implementation, dan Evaluate).

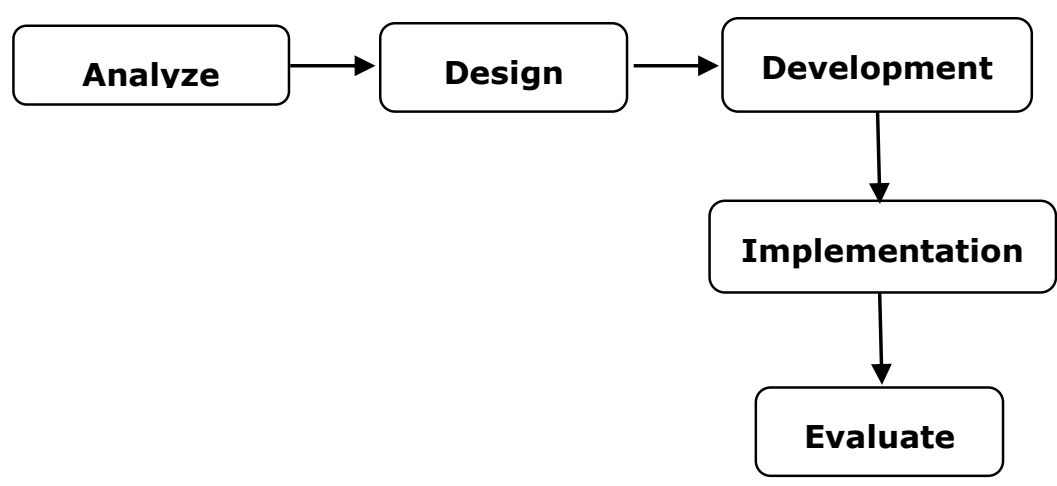

Gambar 3.1 Skema Desain Pembelajaran ADDIE

\section{Metode Pengembangan}

Metode pengembangan media pembelajaran ini menggunakan langkah model pengembangan Borg and Gall) yang disederhanakan oleh Badan Penelitian dan Pengembangan Departemen Pendidikan Nasional (2008), terdiri dari 5 tahapan utama, yaitu 1) Desain awal produk, 2) uji coba produk tahap I, 3) Revisi produk operasional, 4) Uji coba produk tahap II, dan 5) Produk.

\section{Instrumen}

Instrumen dalam penelitian ini menggunakan lembar validasi kelayakan, angket respon siswa, dan lembar saran. Lembar validasi kelayakan untuk validator digunakan mengetahui segi efektifitas dan kepraktisan media yang dikembangkan dengan instrumen mengadaptasi skala likers, sedangkan angket untuk siswa digunakan untuk mengetahui sejauh mana respon siswa terhadap media yang dikembangkan. Lembar saran digunakan untuk keperluan revisi baik desain maupun aturan permainannya.Data hasil lembar validasi dan angket respon siswa yang diperoleh selanjutnya akan dianalisis secara kuantitatif menggunakan skala likert. 


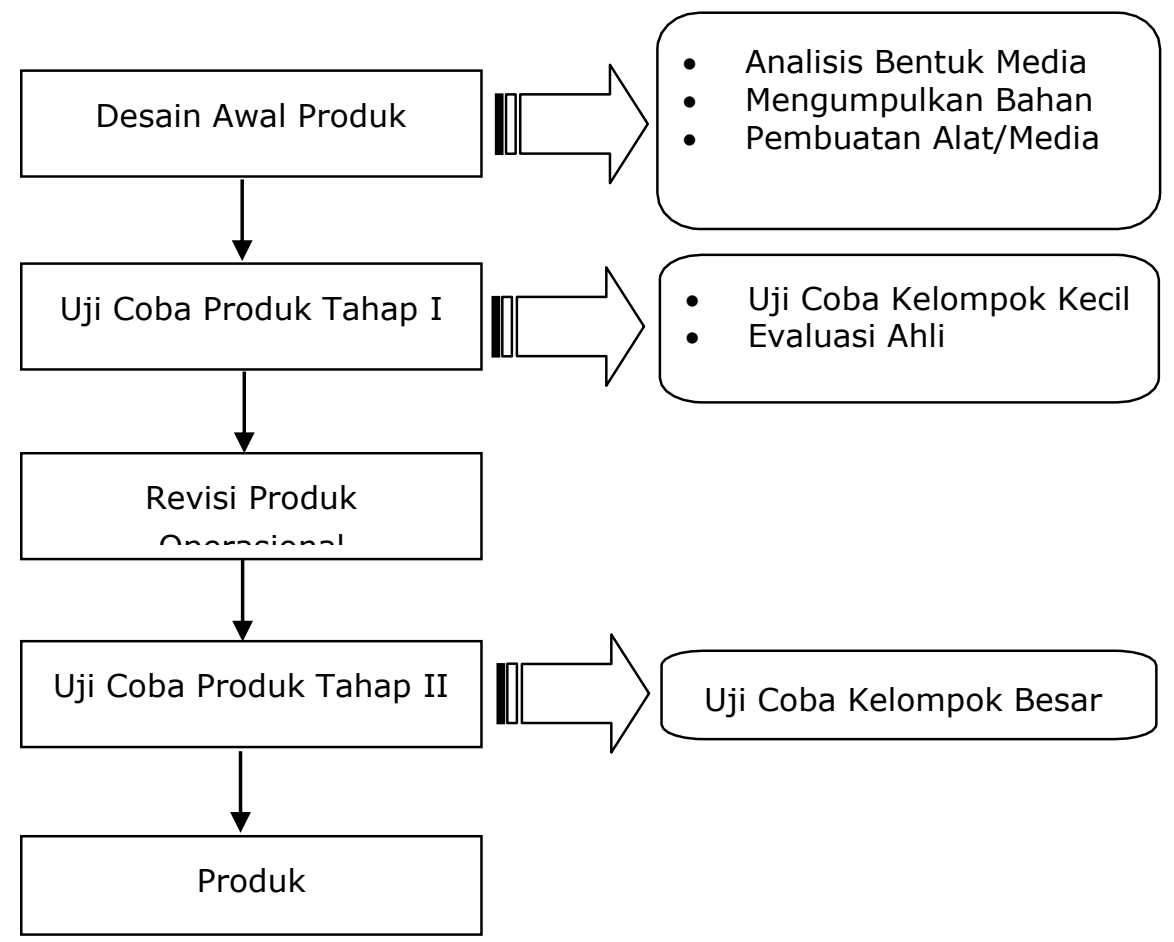

Gambar 3.2 Bagan Alir Metode

Pengembangan Borg and Gall

\section{HASIL DAN PEMBAHASAN}

Media pembelajaran matematika yang

\section{Setting Penelitian}

Penelitian ini dilaksanakan di SMP Negeri 2 Sengkang dengan subyek penelitian siswa kelas VII. 7 sebanyak 28 orang, sedangkan guru junior matematika sebagai teman sejawat dan guru senior matematika SMP Negeri 2 Sengkang sebagai validator yang mengvalidasi, memberi saran, dan membantu dalam dalam uji coba skala kecil dari produk awal yang dikembangkan. Sementara fokus analisisnya adalah aspek keefektifan dan kepraktisan media yang dikembangkan. Apa yang dilakukan oleh masing-masing guru dan siswa dalam percobaan ini. Gambarkan setiap langkah eksperimennya. dirancang diberinama "Permainan Matematika Monopoli Tic Tac Toe" diharapkan bermanfaat untukmembantu guru mengevaluasi siswa tentang penjumlahan dan pengurangan bilangan bulat serta menarik minat siswa untuk mempelajari materi tersebut.

Pada desain awal dilakukan kegiatan menganalisis bentuk media, mengumpulkan bahan, dan pembuatan alat/media. Kegiatan yang dilakukan selanjutnya adalah uji coba kelompok kecil dan evaluasi ahli. Untuk kegiatan uji coba kelompok kecil diuji cobakan dua kali yakni pada dua orang guru dan dua orang siswa. Masing-masing uji coba tersebut akan diperoleh informasi yang menjadi masukan para ahli dalam merivisi desain awal, tampak pada gambar berikut. 


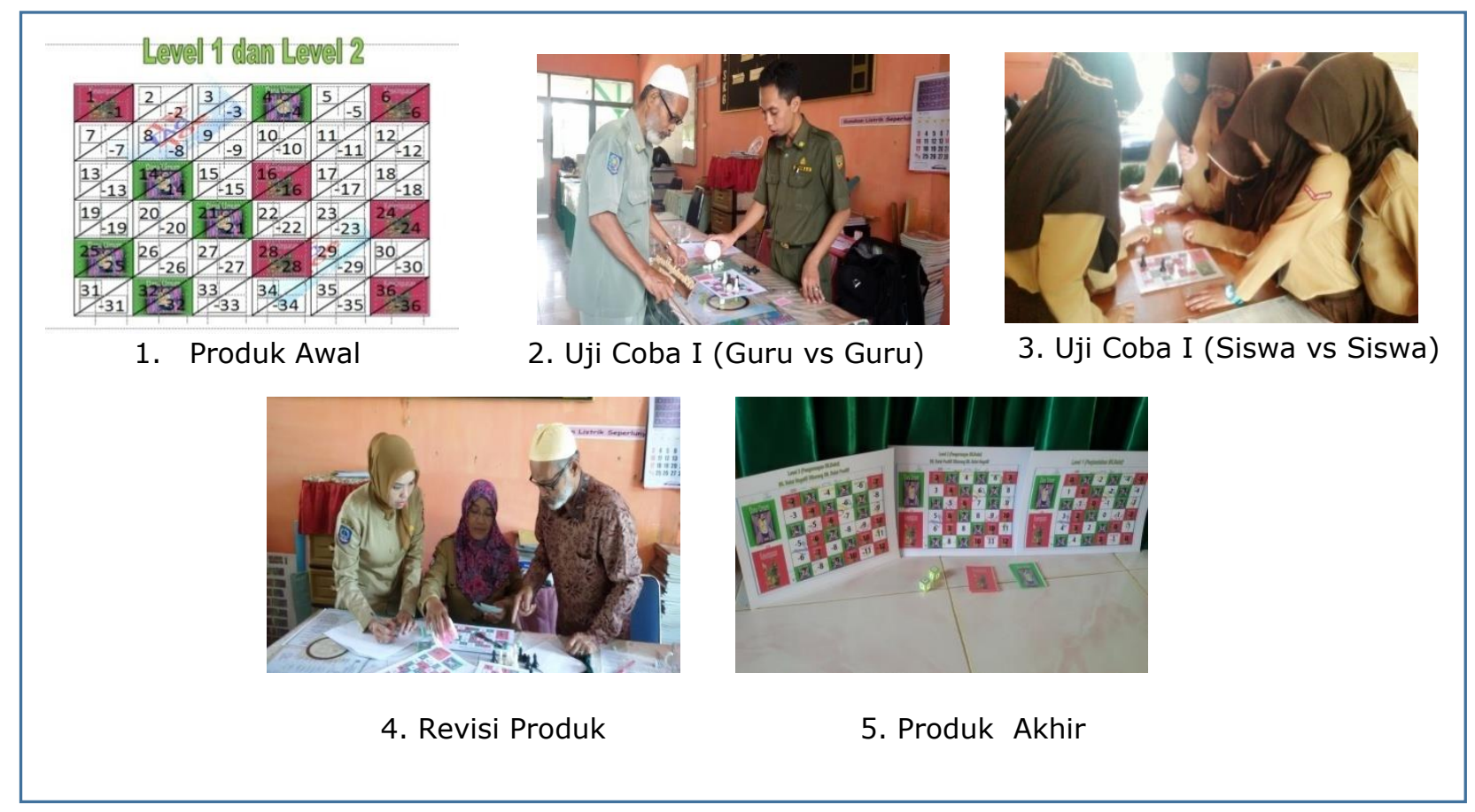

Gambar 1. Alur Kegiatan Pengembangan

Evaluasi para ahli dilakukan oleh guruguru senior matematika SMP Negeri 2 Sengkang dengan memberikan penilaian umum terhadap media pembelajaran yang dibuat berdasarkan aspek penilaian pada lembar validasi. Selanjutnya media pembelajaran direvisi berdasarkan saran para ahli diantaranya petak permainan diperbesar, kartu dana umum dan kesempatan diperbanyak, level permainan dipisahkan sesuai substansi materi, dan petunjuk penggunaan permainan diperjelas. Hasil validasi dari para ahli adalah layak dengan revisi kecil disertai dengan beberapa saran terhadap media pembelajaran rancangan awal. Langkah selanjutnya adalah melakukan perbaikan media pembelajaran berdasarkan saran para ahli.

\section{Hasil Validasi}

Dari serangkaian proses pengembangan telah mengalami revisi baik dari desain awal ,aturan-aturan penggunaan ,bahan maupun ukuran, tampilan warna petak permainan, instruksi kartu dana umum dan kesempatan. Sementara level permainan yang semula disatukan diubah dan dipisahkan menjadi per level. Sedangkan hasil validasi dari instrumen kuesioner teknikLikert skala empat dianalisis seperti tertuang pada tabel di berikut ini 
Tabel 1. Hasil Penilaian Validator terhadap Media Pembelajaran Permainan Monopoli Tic Tac Toe

BIDANG TELAAH

PENJABARAN

KONSEP

KONSTRUKSI

AKTIVITAS

TAMPILAN

KEPRAKTISAN
PENILAIAN

Val. Val. Val. $\bar{V}$ KET

1. Kesesuaian konsep dengan tujuan pembelajaran

I II III

$\begin{array}{llllll}4 & 4 & 4 & 4 & \text { SV }\end{array}$

2. kesesuaian materi dengan tingkat perkembangan intelektual siswa

\section{RATA-RATA}

1. Kejelasan petunjuk penggunaan media

2. Kejelasan gambar

3. Penggunaan bahasa yang sederhana dan mudah dipahami siswa

RATA-RATA

1. Kesesuaian aktivitas dengan tujuan (indikator pencapaian hasil belajar)

2. Manfaat terhadap pembelajaran

3. Peranan media mengaktifkan belajar siswa RATA-RATA

1. Ketepatan ukuran/bentuk media

2. Kesesuaian komposisi warna

3. Kesederhanaan penggunaan media

4. Kesederhanaan desain media

$$
\text { RATA-RATA }
$$

$\begin{array}{lllll}4 & 4 & 4 & 4 & \text { SV }\end{array}$

$4 \quad$ SV

$\begin{array}{lllll}3 & 2 & 3 & 2,67 & \mathrm{~V}\end{array}$

$\begin{array}{llllll}3 & 3 & 3 & 3 & \mathrm{~V}\end{array}$

$\begin{array}{lllll}4 & 4 & 4 & 4 & \mathrm{SV}\end{array}$

$3,22 \quad \mathrm{~V}$

1. Media permainan matematika monopoli tic tac toe dapat dimainkan secara mandiri

2. Media permainan matematika monopoli tic tac toe dapat dibawa ke mana-mana

3. Media permainan matematika monopoli tic tac toe mudah dioperasikan

RATA-RATA

RATA-RATA TOTAL

$\begin{array}{lllll}4 & 4 & 4 & 4 & \text { SV }\end{array}$

$\begin{array}{lllll}4 & 4 & 4 & 4 & \mathrm{SV}\end{array}$

$\begin{array}{lllll}4 & 4 & 4 & 4 & \mathrm{SV}\end{array}$

$4 \quad \mathrm{SV}$

$\begin{array}{llllll}3 & 3 & 3 & 3 & \mathrm{~V}\end{array}$

$\begin{array}{llllll}3 & 3 & 3 & 3 & \mathrm{~V}\end{array}$

$\begin{array}{lllll}4 & 4 & 4 & 4 & \mathrm{SV}\end{array}$

$\begin{array}{lllll}4 & 4 & 4 & 4 & \mathrm{SV}\end{array}$

$3,5 \quad \mathrm{SV}$

$\begin{array}{lllll}4 & 4 & 4 & 4 & \text { SV }\end{array}$

$\begin{array}{llllll}4 & 4 & 4 & 4 & \text { SV }\end{array}$

$\begin{array}{lllll}4 & 4 & 4 & 4 & \mathrm{SV}\end{array}$

$4 \quad$ SV

$3,74 \quad$ SV

Keterangan:

$3,5 \leq \bar{X} \leq 4$ berarti SV (Sangat Valid)

$2,5 \leq \bar{X}<3,5$ berarti SV (Valid)

$1,5 \leq \bar{X}<2,5$ berarti CV (Cukup Valid)

$0 \leq \bar{X}<1,5$ berarti TV (Tidak Valid) 


\section{Hasil Angket Respon Siswa}

Produk akhir yang telah diperoleh di uji cobakan kembali pada kelompok besar yakni siswa kelas VII.7 pada proses pembelajaran di kelas. Pada akhir proses pembelajaran, diberikan angket kepada siswa untuk mengetahui respon siswa terhadap media pembelajaran yang digunakan. Data respon siswa terhadap media pembelajaran merupakan bagian dari evaluasi formatif dari media permainan matematika monopoli tik tac toe yang digunakan dalam pembelajaran. Data yang diperoleh akan digunakan untuk menghitung rata-rata skor banyaknya siswa yang memberi respons positif sesuai dengan aspek yang ditanyakan baik pernyataan positif maupun pernyataan negatif. Selain itu, data ini juga dijadikan acuan revisi bila nantinya siswa memberikan respon negatif seperti tertuang pada tabel di berikut ini

Tabel 2. Hasil Angket Respon Siswa Terhadap Pembelajaran Matematika Menggunakan Permainan Matematika Monopoli Tic Tac Toe

\begin{tabular}{|c|c|c|c|c|c|c|c|c|c|c|c|c|c|c|c|c|}
\hline \multirow{2}{*}{$\mathrm{NO}$} & \multirow{2}{*}{ NAMA } & \multicolumn{15}{|c|}{ NOMOR PERNYATAAN } \\
\hline & & 1 & 2 & 3 & 4 & 5 & 6 & 7 & 8 & 9 & 10 & 11 & 12 & 13 & 14 & 15 \\
\hline 1 & Khohiva Indah Takdir & 4 & 4 & 1 & 4 & 2 & 4 & 4 & 3 & 4 & 1 & 4 & 4 & 4 & 4 & 1 \\
\hline 2 & Rasyid & 4 & 4 & 2 & 4 & 2 & 3 & 3 & 4 & 3 & 1 & 3 & 4 & 2 & 2 & 1 \\
\hline 3 & Febi Lestari & 3 & 3 & 2 & 3 & 1 & 3 & 3 & 3 & 3 & 2 & 3 & 3 & 3 & 3 & 2 \\
\hline 4 & Meliana Nurul Rahmah & 4 & 4 & 1 & 4 & 1 & 4 & 4 & 4 & 4 & 1 & 4 & 4 & 4 & 4 & 1 \\
\hline 5 & Muhammad Akib & 3 & 4 & 2 & 4 & 1 & 3 & 4 & 3 & 3 & 1 & 3 & 3 & 4 & 3 & 1 \\
\hline 6 & Sulindah H.Sultan & 3 & 3 & 2 & 4 & 2 & 3 & 3 & 3 & 4 & 1 & 3 & 3 & 4 & 3 & 1 \\
\hline 7 & Muhammad As'ad & 3 & 4 & 2 & 3 & 2 & 3 & 3 & 3 & 3 & 2 & 3 & 3 & 3 & 4 & 1 \\
\hline 8 & Rezky & 3 & 3 & 2 & 3 & 2 & 3 & 3 & 3 & 3 & 2 & 4 & 3 & 3 & 3 & 2 \\
\hline 9 & Jabal Nur & 3 & 4 & 2 & 3 & 1 & 3 & 4 & 3 & 3 & 1 & 3 & 3 & 4 & 3 & 1 \\
\hline 10 & Selfi Hardiana Ramli & 3 & 4 & 1 & 4 & 1 & 4 & 4 & 4 & 4 & 1 & 4 & 4 & 3 & 4 & 1 \\
\hline 11 & Baso Arya Tirtabuana & 4 & 3 & 1 & 4 & 1 & 4 & 3 & 4 & 4 & 1 & 3 & 4 & 4 & 4 & 1 \\
\hline 12 & Mutamainnah & 3 & 4 & 1 & 4 & 1 & 3 & 3 & 3 & 4 & 1 & 4 & 4 & 3 & 4 & 2 \\
\hline 13 & Irwan & 4 & 3 & 1 & 4 & 1 & 4 & 4 & 4 & 4 & 1 & 4 & 4 & 3 & 4 & 1 \\
\hline 14 & Dhandy Dharmawan & 4 & 4 & 1 & 4 & 1 & 4 & 4 & 4 & 4 & 1 & 4 & 4 & 4 & 4 & 1 \\
\hline 15 & Andi Risda Oktaviani & 4 & 3 & 1 & 3 & 2 & 4 & 4 & 4 & 3 & 1 & 3 & 4 & 4 & 4 & 1 \\
\hline 16 & Pretty Sinta & 4 & 4 & 1 & 4 & 1 & 4 & 4 & 4 & 4 & 1 & 4 & 4 & 4 & 4 & 1 \\
\hline 17 & Asry Wahyuni & 3 & 4 & 2 & 3 & 2 & 3 & 4 & 3 & 3 & 2 & 4 & 3 & 3 & 4 & 2 \\
\hline 18 & Andi Musdalifah Adhe & 4 & 4 & 1 & 3 & 2 & 4 & 4 & 4 & 4 & 1 & 3 & 4 & 4 & 4 & 1 \\
\hline 19 & Salsa Billa Ancha & 3 & 3 & 2 & 3 & 2 & 3 & 4 & 3 & 3 & 2 & 3 & 3 & 3 & 4 & 1 \\
\hline 20 & Irma Suryaningsih & 4 & 4 & 1 & 4 & 1 & 4 & 4 & 4 & 4 & 1 & 3 & 4 & 4 & 3 & 1 \\
\hline 21 & Baso Adam & 4 & 4 & 1 & 4 & 1 & 3 & 3 & 4 & 4 & 1 & 4 & 4 & 4 & 3 & 1 \\
\hline 22 & Muliana & 3 & 3 & 1 & 3 & 1 & 3 & 3 & 3 & 4 & 2 & 4 & 4 & 3 & 4 & 1 \\
\hline 23 & Saheriyanti & 4 & 4 & 1 & 4 & 1 & 4 & 4 & 4 & 4 & 1 & 3 & 4 & 4 & 3 & 1 \\
\hline 24 & Riska Saputri & 4 & 4 & 1 & 4 & 1 & 4 & 4 & 4 & 4 & 2 & 4 & 4 & 4 & 4 & 1 \\
\hline 25 & Zaida Haiyun & 4 & 4 & 1 & 4 & 2 & 4 & 4 & 3 & 4 & 1 & 4 & 4 & 4 & 4 & 1 \\
\hline & Skor Rata-rata & 3,59 & 3,46 & 3,5 & 3,5 & 3,54 & 3,63 & 3,5 & 3,63 & 3,5 & 3,42 & 3,63 & 3,46 & 3,54 & 3,5 & 3,74 \\
\hline & ingan: & & & & & & & & & & & & & & & \\
\hline & Sangat Tidak Setu & & & & & & & & & & & & & & & \\
\hline & : Tidak Setuju & & & & & & & & & & & & & & & \\
\hline & : Setuju & & & & & & & & & & & & & & & \\
\hline & Sangat Ti & & & & & & & & & & & & & & & \\
\hline
\end{tabular}




\section{Wujud Media}

Adapun wujud akhir media setelah mempertimbangkan hasil validasi serta saransaran darivalidator terlihat pada gambar dan penjelasannya sebagai berikut :
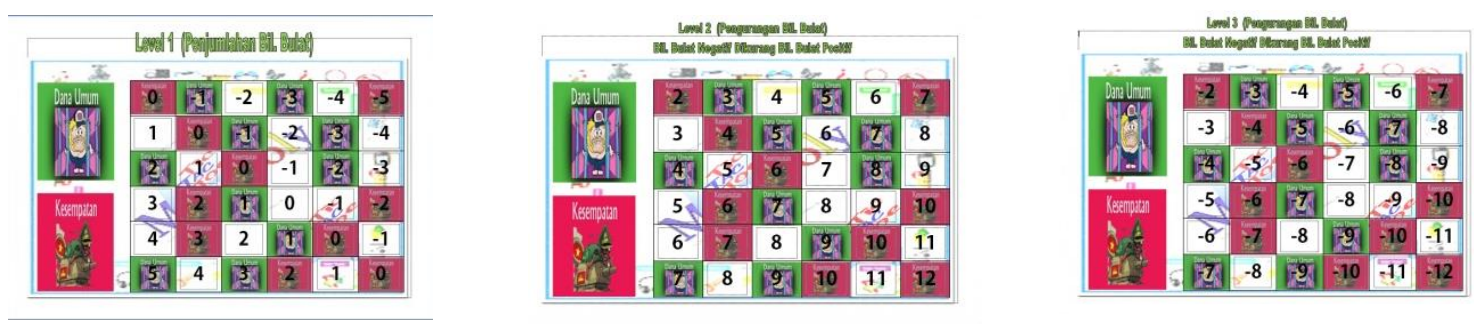

Gambar 2 Papan Permainan

\section{Penjelasan Spesifikasi Media}

Berikut ini petunjuk peggunaan media permainan matematika monopoli tic tac toe: (Langhkah2 ini seharusnya disajikan lebih dahuilu dalam Model Eksperimennya. Disni diceriakan bgn model itu terlaksana, sehingga dapat dikomentari dan dianalisis oleh orang lain)

a. Peralatan

- Papan permainan terdiri dari tiga level yaitu level 1 penjumlahan bilangan bulat, level 2 pengurangan bilangan bulat positif dikurang bilangan bulat negatif, dan level 3 pengurangan bilangan bulat negatif dikurang bilangan bulat positif

- Dua buah dadu (Satu dadu bertuliskan bilangan bulat positif dan satu dadu bertuliskan billangan bulat negatif)

- Kancing berwarna kuning dan biru masing-masing 6 buah

- Kartu kesempatan dan dana umum b. Pemain

- Dimainkan oleh dua orang (satu lawan satu) dan dipimpin oleh seorang wasit (guru atau siswa yang memahami materi penjumlahan dan pengurangan bilangan bulat)

- Tiap pemain diberi 6 buah kancing (Pemain I diberi kancing warna kuning dan pemain II diberi kancing biru)

c. Langkah-langkah permainan:

- Pemain yang pertama kali menggulirkan dadu adalah pemain yang mendapatkan angka terendah atau angka tertinggi (ditentukan oleh wasit)

- Pemain I:

1. Menggulirkan 2 dadu

2. Pemain menjumlahkan angka yang muncul pada sisi atas dadu, misal angka 3 dan -5 maka hasil penjumlahannya -2

3. Pemain menempatkan kancing penanda pada petak yang bertuliskan -2 dan jika pada petak 
tersebut bertuliskan kesempatan atau dana umum, maka pemain mengambil kartu tersebut dan mengikuti instruksi yang tertera pada kartu yang diambilnya.

\section{- Pemain II}

1. Melanjutkan permainan setelah pemain I

2. Langkah selanjutnya sama halnya dengan langkah pemain I

d. Aturan permainan

1. Level yang dimainkan akan berakhir jika salah satu pemain berhasil menguasai 4 petak segaris (horizontal, vertikal, atau diagonal), seperti tampak gambar berikut kancing kuning menguasai 4 petak segaris diagonal dan dilanjutkan ke level berikutnya hingga salah satu pemain memenangkan dua level sebagai pemenang dalam permainan ini.

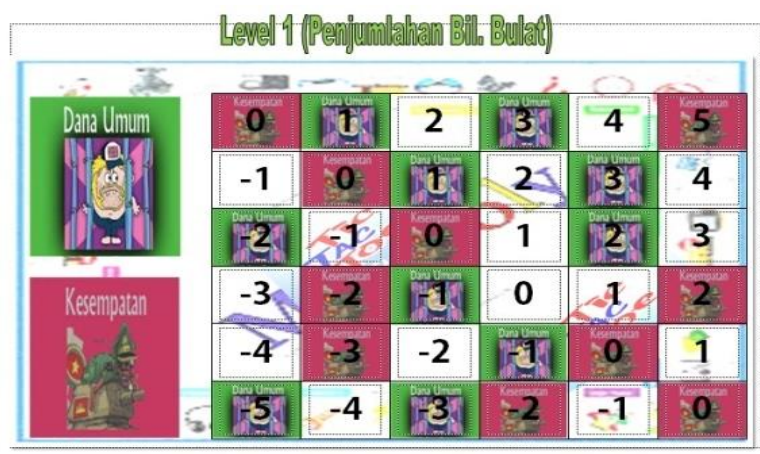

Gambar 4 Posisi Pion di Akhir Permainan

2. Jika seluruh kancing pemain telah berada pada papan permainan dan belum satu pun pemain menguasai 4 petak segaris (horizontal, vertikal, atau diagonal) maka ketika pemain kembali menggulirkan dadu lalu memindahkan salah satu kancing penanda sesuai dengan hasil penjumlahan dari dua dadu tersebut hingga didapatkan pemenangnya.

3. Bila hasil penjumlahan bilangan bulat mendapatkan bilangan yang petaknya sudah ditempati kancing, maka pemain mengulang menggulirkan dadu sampai mendapat petak yang masih belum ditandai.

4. Jika pemain salah menempatkan kancing penanda, maka pemain tersebut harus kembali menggulirkan dadu.

e. Kartu Kesempatan dan Dana Umum

Kartu ini terdiri dari:

1. Kartu serangan, yakni pemain dapat mengeluarkan pion lawan

2. Kartu perisai, yakni pemain dapat bertahan dari serangan lawan

3. Kartu sanksi, yakni pemain mendapat sanksi dari lawan seperti berpuisi, menyanyi, atau hal-hal wajar.

4. Kartu hadiah, yakni pemain mendapat hadiah dari wasit berupa permen.

5. Kartu barter, yakni pemain dapat menukar posisi pion yang dimiliki dengan posisi pion lawan

6. Kartu dadu, yakni pemain mengulangi kocokan dadu

7. Kartu keberuntungan, yakni pemain dapat menempatkan pion ke mana saja yang diinginkan atau dapat melanjutkan satu putaran lagi 
8. Kartu ketidakberuntungan, yakni pemain dapat berhenti satu putaran atau pemain kembali ke awal permainan

Catatan: kartu serangan dan kartu perisai digunakan ketika pemain mendapat giliran

\section{Validasi Media Pembelajaran}

Berdasarkan hasil dari data yang diperoleh melalu instrumen validasi media pembelajaran dan angket respon siswa, maka data-data inilah yang digunakan untuk mengetahui keefektifan dan kepraktisan media permainan matematika monopoli tic tac toe. Hasil analisis masing-masing data sebagai berikut:

1. Nilai rata-rata total kevalidan media pembelajaran yang diperoleh adalah $\bar{X}$ $=3,74$, dapat disimpulkan nilai ini termasuk kategori "Sangat Valid". Jadi, ditinjau dari keseluruhan aspek, media pembelajaran ini memenuhi kriteria kevalidan.

2. Nilai rata-rata kevalidan untuk aspek penjabaran konsep adalah $\bar{X}=4$, dapat disimpulkan nilai ini termasuk kategori "Sangat Valid". Jadi ditinjau dari aspek penjabaran konsep, media pembelajaran dinyatakan memenuhi kriteria kevalidan.

3. Nilai rata-rata kevalidan untuk aspek konstruksi adalah $\bar{X}=3,22$ dapat disimpulkan nilai ini termasuk kategori "Valid". Jadi ditinjau dari aspek konstruksi, media pembelajaran dinyatakan memenuhi kriteria kevalidan.

4. Nilai rata-rata kevalidan untuk aspek aktivitas adalah $\bar{X}=4$ dapat disimpulkan nilai ini termasuk kategori "Sangat Valid". Jadi ditinjau dari aspek aktivitas, media pembelajaran dinyatakan memenuhi kriteria kevalidan.

5. Nilai rata-rata kevalidan untuk aspek tampilan adalah $\bar{X}=3,5$ dapat disimpulkan nilai ini termasuk kategori "Sangat Valid". Jadi ditinjau dari aspek tampilan, media pembelajaran dinyatakan memenuhi kriteria kevalidan.

6. Nilai rata-rata kevalidan untuk aspek kepraktisan adalah $\bar{X}=4$ dapat disimpulkan nilai ini termasuk kategori "Sangat Valid". Jadi ditinjau dari aspek kepraktisan, media pembelajaran dinyatakan memenuhi kriteria kevalidan.

Selain penjelasan analisis di atas, terdapat beberapa revisi yang harus diperbaiki oleh peneliti diantaranya ukuran bentuk media yang perlu diperbesar, kreatifitas warna disesuaikan dengan jenis permainan, petunjuk penggunaan diperjelas dengan rinci, level permainan dipisahkan, kartu dana umum dan kesempatan ditambah, dan penempatan petak kartu dana umum dan kesempatan pada papan permainan ditambah.

Secara umum, validator memberikan penilaian bahwa media permainan matematika monopoli tic tac toe layak untuk digunakan dengan revisi kecil

\section{Respon Siswa}

Analisis Data Angket yang diperoleh melalui angket diolah secara kuantitatif 
menggunakan skala likert. Untuk pernyataan positif dan pernyataan negatif pada angket penskorannya yang dibuat dapat ditransfer dari skala kualitatif ke dalam skala kuantitaif sebagai berikut:

Tabel 4. Kriteria Penskoran Angket Respon Siswa

\begin{tabular}{|c|c|c|}
\hline \multirow[b]{2}{*}{ Alternatif Jawaban } & \multicolumn{2}{|c|}{ Skor Penilaian } \\
\hline & $\begin{array}{c}\text { Pernyataan } \\
\text { Positif }\end{array}$ & $\begin{array}{c}\text { Pernyataan } \\
\text { Negatif }\end{array}$ \\
\hline Sangat Setuju (SS) & 4 & 1 \\
\hline Setuju (S) & 3 & 2 \\
\hline Tidak Setuju (TS) & 2 & 3 \\
\hline Sangat Tidak Setuju (STS) & 1 & 4 \\
\hline
\end{tabular}

Analisis pengolahan data hasil skala sikap siswa adalah dengan cara menghitung rerata seluruh jawaban siswa yang memilih setiap indikator pernyataan. Untuk menghitung rerata skala sikap siswa, menurut Suherman dan Sukjaya (1990: 237) digunakan rumus sebagai berikut:

$$
\bar{X}=\frac{W F}{F}
$$

Keterangan:

$\bar{X}:$ nilai rerata sikap siswa

WF: Jumlah siswa yang memilih setiap kategori

F : Nilai kategori siswa

Setelah nilai rerata siswa diperoleh menurut Suherman dan Sukjaya (1990:237). Jika nilai perhitungan skor rerata lebih dari 2,5 artinya respon siswa positif dan bila nilai nilai perhitungan skor rerata kurang dari 2,5 artinya respon siswa negatif. Rerata skor siswa makin mendekati 4, siswa semakin positif. Sebaliknya jika mendekati 1 , sikap siswa semakin negatif.

Dari hasil data angket respon siswa pada tabel 4 diperoleh bahwa tiap butir pernyataan yang diajukan mendapat respon positif dari siswa. Ini ditunjukkan dari skor rata-rata tiap butir pernyataan lebih dari 2,5. Bahkan rerata skor makin mendekati 4 yang berarti respon siswa semakin positif terhadap penggunaan permainan matematika monopoli tic tac toe dalam pembelajaran.

\section{SIMPULAN DAN SARAN \\ Simpulan}

Salah satu alternative pendekatan/ metode yang disarankan untuk digunakan dalam pembelajaran matematika adalah permainan matematika, sesuai dengan tingkat kemampuan berpikir peserta didik. Memang tidak semua tujuan pembelajaran matematika dapat dicapai melalui penggunaan permainan matematika, akan tetapi beberapa konsep akan lebih mudah dipahami oleh siswa melalui permainan matematika itu, diantaranya adalah materi kelas VII SMP yakni penjumlahan dan pengurangan bilangan bulat.

Melalui media permainan monopoli tic tac toe, ternyata mampu membuat siswa untuk berusaha mencari tahu tentang materi yang diajarkan dan dapat memberikan pengalaman baru yang berarti bagi siswa sehingga mudah mengingat konsep penjumlahan dan pengurangan bilangan bulat yang dibuat dalam bentuk media pembelajaran. Selain itu perlu diingat bahwa permainan matematika bukanlah ditekankan pada segi memberi kesenangan kepada siswa untuk memainkannya, melainkan lebih ditumpukan pada tujuan pembelajaran konsep matematika. Jadi penggunaan permainan matematika hendaknya benar-benar 
dapat membantu peserta didik memahami konsep matematika yang sedang dipelajari, sehingga dapat menumbuhkan dalam diri siswa rasa senang terhadap matematika.

Hal terpenting dari media permainan monopoli tic tac toe adalah jenis permainan ini mudah dibuat, mudah dibawa kemana-mana, dan dapat dilakukan dimana saja secara mandiri serta cara memainkannya pun mudah dipahami, menunjukkan bahwa media ini praktis untuk digunakan.

\section{Saran}

Berdasarkan hasil penilitian ini, peneliti memberikan saran sebagai berikut: (1) Bagi guru-guru matematika, hendaknya dalam pembelajaran tidak menggunakan pembelajaran konvensional. Tetapi menggunakan model pembejaran yang sesuai dengan materi serta penggunaan media belajar. Hal ini dilakukan agar siswa lebih mudah menerima penjelasan matematika sehingga matematika tidak menjadi sesuatu yang abstrak serta siswa lebih termotivasi untuk belajar matematika; (2) seorang guru dituntut kreatif dan berjiwa inovatif dalam mendesain pembelajaran matematika sehingga menarik, efektif, dan efisien dengan cara memanfaatkan sumber-sumber belajar yang ada di lingkungan sekolah; (3) seorang guru hendaknya mampu mengadakan penelitian-penelitian sederhana yang bertujuan untuk menemukan formulaformula baru bagi sistem pembelajaran yang lebih inovatif untuk meningkatkan mutu pendidikan;(4) bagi penentu kebijakan agar kiranya memberikan perhatian yang lebih kepada para peneliti baik melalui bantuan materil maupun pelatihan demi kemajuan pendidikan di daerah pada khususnya dan pendidikan di Indonesia pada umumnya 


\section{PUSTAKA ACUAN}

Abu Syafik. 2012. Permainan Matematika Sebagai Metode Alternatif dalam Pembelajaran Matematika pada SiswaKelas I Sekolah Dasar. Jurusan Pendidikan Matematika. FKIP Universitas Muhammadiyah Purworejo.

Bahri, Syaiful. 2008. Psikologi Belajar. Jakarta : Rineka Cipta.

Benny. Pengertian dan Perkembagan Konsep Media Pembelajaran serta Teori Belajar yang Melandasinya. Dunduh dari http://belajar.kemdikbud.go.id. pada tanggal 17 April 2015.

Burhanuddin. Konsep Dasar Pembelajaran Inovatif. Diunduh dari afidburhanuddin.wordpress.com. pada tanggal 13 April 2015.

Dimyati, dkk. 2006. Belajar dan Pembelajaran. Jakarta: Rieneka Cipta.

Farida. 2013. Angket Respon Siswa terhadap Pembelajaran Matematika Menggunakan Model Problem Based Learning (PBL).Diunduh dari http://faridatulmuna6987.blogspot.com/2013/06/angket-respon-siswa-terhadap.html. pada tanggal 3 Mei 2015.

Hadis, A. 2006. Psikologi dalam Pendidikan. Bandung: Alfabeta.

Nana,Syaodih dkk. 2007. Metode Penelitian Pendidikan. Jakarta: Remaja Rosdakarya.

Pusbanglitbang. 2008. Pedoman Penelitian dan Pengembangan. Jakarta: Depdiknas.

Ramadhan, A. Tarmizi. (2008). Pembelajaran Aktif, Inovatif, Kreatif, Efektif, dan Menyenangkan. Diunduh dari tarmizi.wordpress.com. pada tanggal 17 April 2015.

Sabila, Ervinda.Desain Pembelajaran. Diunduh dari http://ervindasabila.blogspot.com. pada tanggal 13 April 2015.

Salman, M. 2007. Pemanfaatan Teknologi Informasi dan Komunikasi (TIK) dalam Pencapaian Standar Nasional Pendidikan yang Terkait dengan Pembelajaran Matematika. Kelompok Keahlian Matematika Kombinatorika Fakultas Matematika dan Ilmu Pengetahuan Alam Institut Teknologi Bandung.

Sardiman. 2011. Interaksi dan Motivasi Belajar Mengajar. Jakarta. Rajawali Pers.

Setyana, Putra. Perencanaan, Pembelajaran dan Model Pembelajaran ADDIE. Diunduh dari putrawijilsetyana.wordpress.com.pada tanggal 17 April 2015. 
Sigit, dkk. 2008. Pengembangan Pembelajaran dengan Menggunakan Multimedia Interaktif Untuk Pembelajaran Yang Berkualitas. Karya Tulis: Disajikan pada Lomba Karya Tulis Ilmiah Tingkat Fakultas FIP Universitas Negeri Semarang pada Tanggal $2-3$ April 2008di Gedung Serbaguna FIP.

Suherman, dkk. 2003. Strategi Pembelajaran Matematika Kontemporer. Bandung: Universitas Pendidikan Indonesia.

Sukayati. 2009. Pengembangan Media Pembelajaran Matematika. Yogyakarta: PPPPTK Matematika

Syah, Muhibbin. 2009. Pembelajaran Aktif, Inovatif, Kreatif, Efektif, dan Menyenangkan (PAIKEM).PLPG Rayon Fakultas Tarbiyah dan Keguruan. Bandung: UIN Sunan Gunung Djati.

Trianto. 2007. Model Pembelajaran Terpadu dalam Teori dan Praktek. Jakarta: Prestasi Pustaka.

Wanda. Model Pembelajaran Monopoli Paikem. Diunduh dari https://dossuwanda.wordpress.com. pada tanggal 22 April 2015.

Wibowo. 2013. Sejarah Permainan Tic Tac Toe. Diunduh dari http://kotaksederhana.blogspot.com/. pada tanggal 21 April 2015 